\title{
Decolonising the Curriculum in International Law: Entrapments in Praxis and Critical Thought
}

\author{
Mohsen al Attar ${ }^{1}$. Shaimaa Abdelkarim²
}

Accepted: 12 October 2021 / Published online: 18 November 2021

(C) The Author(s) 2021

\begin{abstract}
Calls to decolonise the curriculum gain traction across the academe. To a great extent, the movement echoes demands of the decolonisation era itself, a period from which academics draw both impetus and legitimacy. In this article, we examine the movement's purchase when applied to the teaching of international law. We argue that the movement reinvigorates debates about the origins of international law, centring its violent foundations as well as its Eurocentric episteme. Yet, like many critical approaches toward international law, the movement is smitten with itself and with the regime. As a consequence, the outcome of its activism and critique is predetermined: both must redeem the Eurocentrism of international law and its associated pedagogy. Calls to decolonise the curriculum ultimately validate the epistemological limitations inherent to a stratified, international order, failing to offer a genuine alternative framework or epistemology.
\end{abstract}

Keywords Decolonisation · International law $\cdot$ Decolonising the curriculum movement $\cdot$ Eurocentrism $\cdot$ International legal pedagogy

\section{Introduction}

International law is difficult to teach. As a field of study, it stands apart from most others in the discipline. The protagonists are formal (nation-states), informal (TNCs), eclectic (monarchies and republics alike), and mundane (institutions and courts); its reach is both formidable (everything) and superficial (on a voluntary basis); and its theoretical (positivist or natural), cultural (African, Asian, or

Mohsen al Attar

mohsen.alattar@ucl.ac.uk

Shaimaa Abdelkarim

s.abdelkarim@bham.ac.uk

1 Faculty of Laws, UCL, London WC1H 0EG, UK

2 School of Law, University of Birmingham, Block 1, University of Birmingham 42, 1 The Tennis Court, Birmingham B15 2RE, UK 
Caribbean), and epistemological (divine, rational, or Eurocentric) credentials are layered and chequered.

In further contrast, international law demands rigorous grounding in global history, political economy, and political philosophy. Absent these foundations, students will find the evolution of international law, guided by the melding of geopolitical events, normative imagination, historical contingencies, and structural biases difficult to grasp. When lecturing about international law, deciding where to begin is as difficult as deciding where to end and which path to take. Yet, despite international law's distinctiveness, its import and popularity grow, provoking the need for deeper engagement with the associated pedagogy.

Increasingly at law faculties around the world, this engagement manifests via the decolonising the curriculum movement. At its core, the movement is motivated by the concept of epistemic violence. Much of the colonial project involved superimposing a European knowledge system over all others, devastating local cultures and denigrating local ways of knowing. As far back as the 1980s, postcolonial scholars such as Edward Said and Gayatri Spivak critiqued the stratification of epistemology endemic to colonisation to capture the cognitive character of the exercise (Said 1978; Spivak 1988). Since then, Annibal Quijano, (2000), Walter Mignolo and Catherine Walsh (2018), and others have advanced the argument under the decoloniality banner, arguing that notions of modernity, liberalism, and being are riddled with prejudice. We note varied attempts to transpose postcolonial and decolonial scholarship to international law, beginning with some of the earlier studies on the violence of legal transplants and the later ones on the artifice of universalism.

Both decolonisation and decoloniality pervade debates about tertiary education and legal pedagogy, with much international law susceptible to epistemological deconstruction. Almost paradoxically, the decolonising the curriculum movement gains its substantive and symbolic traction from the incompleteness of the decolonisation project. As a processual pursuit, decolonisation denotes independence struggles of colonised societies. Political independence, economic sovereignty, and human freedom intermingled to varying degrees to produce the putative postcolonial world. To decolonial scholars, decolonisation is an incomplete project, a form of semi-freedom or un-freedom. Their bugbear is not with forms of neocolonialism, but with the epistemic violence that is casual in the postcolonial. The latter is subtle, achieved by mainstreaming a worldview that bolsters the status quo. Even conversations about sovereignty, state practice, uti posseditis, and customary law, to name a few, presuppose the validity of the colonial foundations upon which they rest. To paraphrase Sundhya Pahuja, (2011), decolonising states were born into law. Yet, these foundations are historically contingent and culturally prejudicial, with a single worldview continuing to occupy the centre-ground. Those who apply a decolonial critique thus take aim at epistemology, treating everything else-including the decolonisation era-as symptoms of epistemic authoritarianism. ${ }^{1}$ By applying a decolonial

\footnotetext{
${ }^{1}$ For discussions on decolonial theory and colonial epistemologies, see Mignolo and Escobar (2010), Mohanty (2003), Lugones (2010).
} 
critique, scholars unearth the perversions of Eurocentrism that pervade international law. $^{2}$

In our contribution to the debate, we explore both the necessity and impossibility of decolonising international law and, by extension, the tension in decolonising its pedagogy. We begin by contextualising the calls to disabuse international law of its Eurocentrism. This begins with its origins that inform its praxis and penetrate its operations. Central to our analysis of the origins of international law are the afterlives of colonialism that entrench its epistemic function. This is especially problematic for international legal pedagogy as the teaching of international law demands engagement with its structure, irrespective of its Eurocentric past and its blinkered present. To teach international law is to augment Eurocentrism within its praxis, and the alternatives are limited and unsatisfactory.

Our second section unpacks decolonisation both as revolutionary and reactionary practices, investigating the implications of applying a decolonising thrust to education. Sovereignty, but not always self-determination informs local independence struggles. As a culturally and historically contingent frame, freedom and subjugation commingled to produce the postcolonial identity. How do these tensions play out when scholars decolonise their curriculum? As we demonstrate, this is a historical movement, with both indigenous groups in settler-colonial states and post-apartheid South Africa pursuing similar efforts. At its core, the aim was to restructure knowledge production, as exemplified in the Arusha Declaration. While their practices were not well received, they do provide grounding for the modern movement and, yet, the modern movement mostly disavows its historical antecedent. The desire for a collective point of mobilisation caused advocates of decolonisation to strip the praxis of its nuance and contradictions. Moreover, contrary to what is intimated via the movement's moniker, decolonisation never aimed to dismantle Eurocentrism. Rather, it legitimised Western epistemic traditions, subverting anti-colonial struggles once more. Failure to account for this nuance, hampers the movement's potential, by denying the prevalence of counter-revolutionary forces committed to the status quo.

Building on this argument, we explore in part three the institutional constraints that limit the movement's aspirations. As state and market subsidised sites of knowledge production and transfer, universities are conservative in character, beginning and ending with their law faculties. In contrast to individual academics, who may be as radical as the revolutionaries of yesteryear, the university as an institution is committed to a palatable form of decolonisation. Arguing equality and diversity, the movement allows everyone to participate in whichever capacity they deem adequate, with a slight variation to the present masquerading as a political position. International legal scholars are much the same. They curb the movement's aims by beginning from a colonial endpoint: the legitimacy of Eurocentric international law. We conclude by substantiating our doubts about the cogency of the movement.

\footnotetext{
${ }^{2}$ On decolonial theory in international legal praxis, see Achiume (2019), Barreto (2018), Nesiah (2018). Natarajan et al. (2016), Pahuja (2011).
} 
Part four links the preceding sections together, substantiating our overall thesis: to our great chagrin, the decolonising the curriculum movement reproduces the epistemological closures that characterise international legality. To a large extent, the movement is guilty of the behaviour it condemns. Like much critical international legal scholarship, the movement re-enchants international law as a decolonised and decolonial order. In the process, it coopts conversations about the imperative of actual freedom that the movement contends international law strengthens.

In the final part, we problematise the movement's desire to teach international law differently. Following an examination of the strategies on offer, we suggest a process of disenchantment with international legal praxis that, first, reaffirms racial identification and, second, tackles the rehabilitative aims in critical pedagogies that preserve the colonial condition.

\section{Does International Law Require Decolonising?}

In the study of academic disciplines, scholars foreground historical origins as a logical entry point to lessons about doctrine, methodology, interpretation, and critique. Modern international law is much the same with each textbook advancing a narrative about its complicated origins. But when did international law begin? Who established it and for what purpose? A key conundrum for teachers of international law is our inability to identify a single starting point, a substantial dilemma that undermines our understanding of the logic that adumbrates relations between states.

Many critical scholars situate Cristobal Colon and Francisco de Vitoria, purveyors of the doctrine of discovery, at the beginning (Anghie 2003). Colon's voyage to the region now known as the Caribbean set the wheels in motion. Who did he encounter? Were they sovereign, like the Italian captain's Spanish patrons? Did they owe one another legal responsibilities and rights? Colon did not live long enough to hear Vitoria's answers which, according to Antony Anghie, precipitated an era of legalised conquest. Vitoria argued that jus gentium obligated the natives, foremost, to trade with the Spanish. While this sounds innocuous, when combined with the latter two obligations, it proved devastating: the natives must also allow the Spanish to settle their lands (right to sojourn) and to save their souls (right to proselytise). The same obligations bound the Spanish, to be sure, though Vitoria deemed the natives' incapacity for transatlantic travel inconsequential; the possibility alone sufficed. With tautology and sleight of hand, Vitoria achieved what other Catholic jurists could not, codifying Catholic doctrine in a now universal system of international law, one that delegitimised non-Catholic ways of being. While modern publicists often disclaim this inconvenience, the most common story about contemporary international law's birth begins with the genocidal campaigns Europeans carried out from the sixteenth century onwards.

Some scholars prefer not to trudge as far back in history when teaching the subject. They present the Peace and Treaty of Westphalia, the compromise between Catholics and Protestants, as the foundation of the modern nation-state and thus also the foundation of modern international law. Of import to the Westphalian narrative is the platform through which negotiations between nation-states 
would henceforth take place. It was no longer a matter of ceremonial tête-a-têtes between nobilities, but of the codification of outcomes that would engender binding obligations. Grotius is key here. Despite the partiality of his reflections-developed to vindicate the activities of his employer, the Dutch East India Companythey formed the foundation of a burgeoning system of international law, European in character and advantage, but international in application.

A third possible starting point for international law arrives arm-in-arm with colonialism. European expeditions into the Americas, Asia, and eventually Africa produced not just genocide but also conquest and settlement, all of which aligned with Vitoria's jus gentium and Grotius's Law of the Seas. To these jurists, we should add their successors, Emer de Vattel and John Westlake, who also argued in favour of appropriating the lands of others (Anghie 1999). Between the seventeenth and twentieth centuries, Europe facilitated the transfer of peoples from its states and forced the transfer of peoples from the proto-states of others to the lands it conquered. Colonial governments drew up sophisticated legal arrangements that regulated activities between European states, between European states and colonised societies, and between European states and private actors (usually companies but sometimes individuals as well). These arrangements were legal in form and character, creating rights and responsibilities that, even today, remain enforceable. In this way, genocide, slavery, conquest, and colonialism, all of which took place under cover of legality during a 400-year expanse, were part of the development of international law. Colonial practices are thus not aberrations to the legal regime but foundations in its development, as argued by many Third World Approaches to International Law (TWAIL) scholars (Natarajan et al. 2016).

A fourth starting point is not represented by a moment but a period: the era of decolonisation. Decolonisation, some argue, finally gave rise to a universal international legal regime. For example, in his textbook, Malcolm Shaw uses decolonisation to evidence the Third World's embrace of the European iteration of international law: 'The new nations have eagerly embraced the ideas of the sovereignty and equality of states and the principles of non-aggression and non-intervention, in their search for security within the bounds of a commonly accepted legal framework (2017, p. 29).' They joined the General Assembly in droves, they came to populate the bench of the International Court of Justice, and they even supported peacekeeping missions and ad hoc regional tribunals. However parochial were its origins, international law was now universalist in consent, if not in character (Shaw 2017, p. 29). To represent decolonisation as evidence of a consensus in support of the legitimacy of European international law is misrepresentative, unless we do as Shaw does and omit the history of the decolonisation struggles including, foremost, European resistance thereto as the Algerians, Angolans, Egyptians, Palestinians, and Vietnamese learned at great collective cost. Like the brutality of colonisation, the violence of decolonisation is also part of international legal history. Moreover, however legitimate it was for Third World states to pursue decolonisation, the path boosted the legitimacy of European international law. As we argue in the forthcoming sections, just as a Eurocentric bias prevails in international law, so too does it manifest within 
discussions about decolonisation. At the heart of this article about decolonisation and international legal pedagogy is the centrality of Europe, the lands of others, and the manifold strategies by which Europe sought to retain control over these lands.

Attempts to appropriate decolonisation as a progressive counter-narrative to European international law are tactical rather than historical. The movement capitalises on symbolism, on one hand, and idealism, on the other. Yet, the embrace of decolonisation is also the legitimation of European international law, including its macabre origins. That the movement avoids this inconvenience is largely because of the wider avoidance of epistemology in debates about international law. 'Western epistemic traditions are traditions that claim detachment of the known from the knower,' according to Achille Mbembe, '[t]hey rest on a division between mind and world, or between reason and nature as an ontological a priori' (2016, p. 32). The denial of the subjectivity of European epistemology is itself epistemological: 'The knowing subject is thus able to know the world without being part of that world and he or she is by all accounts about to produce knowledge that is supposed to be universal and independent of context' (Mbembe 2016, p. 33).

Decolonisation was violent because colonisation was brutal. European states are loath to admit this for it seeds doubt into the entire edifice of international law. While some international legal scholars can shield themselves with the veil of ignorance-most textbooks are formalist in character-others know better. Their reluctance to engage with history and with epistemology as they pertain to international law is not malicious. Rather, it is borne of our own education. As it is, international law conveys the image of Europe unto the world. It is a Eurocentric subjectivity posing as universal objectivity. Non-Europeans can embrace it, as they have, and it can even morph into their subjectivity as well. We are led into the crux of the conundrum: international law must be decolonised, but it cannot. Its entire framework, even its legitimacy is derived from colonial ambitions and forms of governance.

We thus pose the obvious question: which of the four narratives should a decolonising approach to pedagogy adopt? If international law is shot through with imperial conquest, is it possible to decolonise international legal history? These issues are brought to the fore by the Eurocentric representations of international law conveyed by textbooks but, perhaps more damningly, by the Eurocentrism of international law itself. Regardless of the story we favour, all four situate Europe and European subjectivity at the heart of international law. Neither colonial history nor decolonial resistance coheres with the sanitised representation of international law that these narratives advance. Their shared brutality is regarded as unfortunate, maybe even shameful, but irrelevant to the legitimacy or operation of the regime; we need not throw the baby out with the bathwater. More important for our analysis, is the second consequence. Acceptance of Eurocentric international law ensures that critique does not subvert the established canon. As we discuss in the remainder of the article, acceptance of international law as it purports to be produces an epistemological entrapment that corrals international law's possibilities.

In the following section, we consider the implications of this conundrum for attempts to decolonise tertiary education. Our emphasis is on approaches to the teaching of international law. 


\section{Decolonising Education}

In 2015, students at the University of Cape Town launched the Rhodes Must Fall campaign, demanding that the university remove a statue of Cecil Rhodes. The commemoration of a notorious colonialist and brigand was too much to bear in post-apartheid South African society. Denunciation of the statue provided the spark, but the campaign swiftly evolved into a sweeping call to decolonise the curriculum (Mamdani 2016). Participants in the movement urged a re-examination of colonial legacies in all their manifestations, especially the influence they exert over student learning. So salient were the demands that the campaign grew global, challenging manifestations of colonialism at universities across South Africa but also beyond including the UK, Australia, Canada, New Zealand, and the USA, younger states denoted by shared histories of genocide, settler colonialism, and epistemic erasure.

That the decolonising the curriculum movement should emerge in South Africa is understandable. Since the $90 \mathrm{~s}$, the South African tertiary sector has rethought 'the Eurocentric and white-male dominated canon of knowledge on which South African schools and universities were founded' (Goduka 1996, p. 27). A white curriculum not only effaces blackness but also empowers whiteness, the opposite of the inclusivity agenda sought for post-apartheid reconciliation. Subverting the legacies of colonialism through a broad-based affirmation required the adoption of curricula that reflect all students and staff. 'Why is it important to affirm diversity in traditionally white universities in South Africa?' Goduka asks and answers: 'Demographic realities of student populations on white campuses, political pressures, educational necessities, and more imperatives point to the need to move beyond the deficit model (norm) which assumes that different is equal to deficient and therefore inferior, and the belief in the superiority of one race over others in order to affirm our similar yet diverse nature' (1996, p. 30). To redress historical inequities, a postcolonial society must cater to the needs of all constituencies, with special emphasis on those traditionally excluded. Fastforward twenty years and South African education remains Eurocentric, precipitating the Rhodes Must Fall campaign.

Scholars interspersed across the world chimed in. Michael Peters, at the University of Waikato in the heart of Aotearoa, penned an essay on decolonisation entitled Why is my Curriculum White? He highlights the normalisation of whiteness in education: "white ideas" by "white authors"...is a result of colonialism that has normalised whiteness and made blackness invisible' (2015, p. 641) His repeated use of the white qualifier appears redundant but proves essential in underscoring the omnipresence of a dominant white episteme in tertiary education. Curricular choices are teleological, shaping not just what students read but also privileging particular histories and constructions of knowledge. Peters leaves us pondering how decolonisation practices might redress the pattern in tertiary institutions.

As per our preceding section, decolonisation has a textured history. Calls for decolonisation in the early days of the postcolonial period targeted the dynamics 
of the education system at large. In colonial settings, this involved extending educational opportunities to Black and Indigenous communities. Routinely excluded from colonial universities, these communities were denied adequate secondary and university education. To decolonise during the colonial period involved making education universally accessible. In settler-colonial states, the demands were often driven by an acceptance of the need to cohabitate. They insisted on representation, both as students and lecturers, pursued through programmes of positive discrimination.

To some pan-Africanists and Third World revolutionaries, these perspectives on decolonisation were too timid, failing to address the core colonial question: from which knowledge system should a postcolonial educational system-or people for that matter-draw upon? They argued that if local systems were to thrive, postcolonial societies must look beyond European epistemology. Ngũgĩ wa Thiong'o is perhaps the most well-known advocate of this position. In his Farewell to the English Language essay, Ngũgĩ articulates the position with poetic charm.

The effect of a cultural bomb is to annihilate a people's belief in their names, in their languages, in their environment, in their heritage of struggle, in their unity, in their capacities and ultimately in themselves. It makes them see their past as one wasteland of non-achievement and it makes them want to distance themselves from that wasteland. It makes them want to identify with that which is furthest removed from themselves; for instance, with other peoples' languages rather than their own. It makes them identify with that which is decadent and reactionary, all those forces which would stop their own springs of life. It even plants serious doubts about the moral rightness of struggle. Possibilities of triumph or victory are seen as remote, ridiculous dreams. The intended results are despair, despondency and a collective death-wish. Amidst this wasteland which it has created, imperialism presents itself as the cure and demands that the dependant sing hymns of praise with the constant refrain: 'Theft is holy'. Indeed, this refrain sums up the new creed of the neo-colonial bourgeoisie in many 'independent' African states (Ngũgĩ wa Thiong'o 1986, p. 3).

Despite his accomplishments as a scholar of English literature, Ngugi ceased writing in English in works of fiction in 1977 and of non-fiction in 1983. He opted to publish in his native Kikuyu to aid in the development of the culture and identity of Kenyan peoples. 'The choice of language and the use to which language is put is central to a people's definition of themselves in relation to their natural and social environment, indeed in relation to the entire universe.' (Ngũgĩ wa Thiong'o 1985, p. 109-10) To Ngugi, postcolonial societies struggling to recover from the trauma of Eurocentrism, should begin by developing the capacity to self-define 'time and space' (Ngũgĩ wa Thiong'o 1986, p. 4). To him, as a conveyer and incubator of culture and cognition, language is primordial in this struggle.

Ngugi's position, radical for some, is epistemological in character and captures the essence of the decolonising the curriculum movement, one that manifests virulently in the pedagogy of international law. The cultural bomb he laments represents 
the epistemic violence upon which modern international law was founded. As detailed above, no scholar can argue against the brutalities from which international law was born. Yet, we are told that, irrespective of the regime's Eurocentric and colonial history, non-European societies must accept it wholesale. 'However unfair and skewed is the history of international law, an international legal system [exists]' according to Ebrahim Afsah, and 'any other system built to mediate the interests of hostile states would look very much the same' (Anghie and Real 2020, p. 30). In keeping with Ngugi's cogent observation, arguments about the legitimacy, even supremacy of Eurocentric international law are often made most forcefully by scholars from or with ties to the Third World. They, too, are willing to disregard the regime's nefarious origins.

For his part, Ngugi and those of his inclination prefer to restructure knowledge production and to value local epistemological systems. In the context of curriculum reform, this position is exemplified in the Arusha Declaration's proposed socialist reform of education (Mamdani 2016). As per the declaration, attending to curricular reform was not an institutional endeavour alone, but a social and political practice reflective of the anti-colonial drive for recognition in postcolonial societies. The reforms aimed to de-racialise societal ties. As Mamdani documents, the institutional response to the declaration at the University of Dar es Salam varied in three distinctive voices: a radical one that sought to abolish disciplinary boundaries, a moderate one that wished to reform curriculum while promoting interdisciplinarity, and a conservative one that resisted curricular changes and favoured rigorous disciplinary boundaries. Yet, the debate went beyond curricular politics and extended to student and staff activism (Mamdani 2016).

Much was said about the need to nurture a postcolonial identity in support of the nation-state and many Third World universities were born of this premise, mediating the tension between the promotion of nationalism alongside the curbing of European predilections in pedagogical practices. The nationalist response acknowledged precolonial knowledge structures, like that of Al Azhar in Cairo, Sankora in Timbuktu, and Al Qarawiyeen in Fez. Still, while attending to the demands of modernity, the postcolonial nationalist response subordinated these orders of knowledge within the structure of a modern university (Mamdani 2016). The reforms that came out of the 1960s anti-colonial movements were inclined to refocus the role of the university on pleas of democratisation against imperial, nationalist governments while dismissing the calls of scholars like Walter Rodney in Tanzania on attending to anti-colonialism in paving the process of post-independence.

These epistemological demands were met with repression on one hand and cooptation on the other as the purpose of non-Western academic institutions was reduced to the application of Western theory. This is evident in the chasm that Mamdani traces between the agencies of the 'black public intellectual' who was doing the anti-colonial ground work and the 'white scholar' who was an ally of decolonisation in the post-independence period. Whereas the public intellectual worked on local grounds, the scholar acquired a universal and objective resonance. Today, this split manifests in the totalising function of knowledge production as the intellectual/ scholar and students are turned into depoliticised mimic specialists who are 'learning to apply a theory produced elsewhere' (Mamdani 2016, p. 81). 
Our synopsis does not do justice to the nuances of anti-colonial effort. But, to understand decolonisation as period, process, and aspiration requires engaging with the full breadth of its spectrum, while attending to the layers of anti-colonial agencies that outdid pleas of decolonisation and sovereign recognition. Failure to do so results in the reproduction of many of the social dislocations endemic to colonisation including epistemic violence, as South Africa eventually discovered. It is in this light that we must reflect on the call to decolonise the international legal curriculum. In the context of international legal pedagogy, we must answer two fundamental questions: what does the movement propose to decolonise and how? To decolonise international law, like any law, compels the subversion of the status quo, itself a contentious act within the dominant epistemology. The symbolism of decolonisation supplants its substance, exposing the limitations of the movement, as we explain in the following section.

\section{Decolonise the Curriculum}

To reiterate, decolonisation is a contingent process. It is intertwined with histories of invasion and settler-colonialism, of exclusion and assimilation, and of independence and identity. Most of all, the history of decolonisation is the history of resistance and of counter-revolution: colonised peoples sought to shake off the shackles of oppression while colonisers, both internal and external, sought to concretise them. This framing of the aspiration is essential in situating the character of the exercise. It was always going to be oppositional for one party was destined to lose the privileges they acquired at the expense of the other. In the much the same way as white supremacy opposed positive discrimination, so too do the descendants of colonisers resent any intervention that will erode their advantages. With an adversarial backdrop, we consider some of the ways in which decolonisation has materialised in universities.

At its most basic, decolonising the curriculum involves diversifying reading lists. A student group at the University of Kent produced a manifesto on decolonisation in which they highlight 'the colour of [the] curriculum' as their entry point into the debate: 'We need a diversity of perspectives, particularly from scholars of colour and from the global south (including access to reading lists from around the world), so that our curriculum reflects and addresses a range of experiences and promotes cultural democracy, as well as developing all students into critical and analytical thinkers and leaders within their education' (Ahmad et al. 2019, p. 6). As one student observed, 'it was literally white male theorists all the time' (Ahmad et al. 2019, p. 7). Another remarked that the 'only time we look at non-white material is in relation to colonialism and extremism and the material tends to be negative' (Ahmad et al. 2019, p. 6). Both empirical and anecdotal evidence verifies the commonality of exclusion.

Much can be gained from a diversified reading list for marginalised communities. We've already discussed the case of South Africa, a promising study when challenging viewpoints that perpetuate colonial structures: 'there is something profoundly wrong when...syllabuses designed to meet the needs of colonialism and apartheid should continue well into the liberation era' (Mbembe 2016, p. 32). A colonial 
syllabus is designed to entrench 'white and Western dominance and privilege' by mainstreaming 'stereotypes, prejudices and patronising views about Africa and its people' (Heleta 2016, p. 2). By introducing students to scholars from outside the Eurosphere, academics create opportunities for a range of viewpoints to collide. Exposure alone disrupts the inherited curriculum, upon which many of today's inequities sit.

A diversified reading list will also benefit universities in the metropoles. Notice that students at Kent and UCL, Ottawa and Oxford also mobilised against the hegemonic character of their curricula. The internationalisation of tertiary education has created a free flow of students from varied regions of the world. You can imagine their surprise when the majority of the scholars they read are white, male, and dead. A diversified reading list would at least support cultural recognition, helping them appreciate the importance of civilisational literacy to their education. Similarly, diversification advances the cause of equality. By including scholars from diverse backgrounds, we inspire students who are traditionally underrepresented or absent in the academe. Even if only symbolic, seeing oneself in scholarship can have a profound impact on self-esteem and aspiration. 'Descriptive representation refers to the premise that a representational artefact should resemble the community from which it is drawn' (Bird and Pitman 2020, p. 905). Imagine, for example, a reading list composed of all male scholars for a course on feminism. Just as this would be offensive, so too is the over-privileging of whiteness in curricula. Diversifying readings lists are thus vital to the aim of decolonisation.

Demonstrating pedagogical and political acumen, student groups did not limit their critique to the colour of the scholars, separating white people from the pathology of whiteness: 'the white curriculum need not only include white people' (Peters 2015 , p. 643). Race, they remark, is 'an ideologically constructed social phenomenon...that empowers people racialised as white' (Peters 2015, p. 643). Curricula are white, Peters contends, because academics make whiteness invisible, at least to white academics and white students. Quoting Audre Lorde, Sara Ahmed argues that 'whiteness works precisely by assigning race to others: to study whiteness, as a racialised position, is hence already to contest its dominance, how it functions as a "mythical norm"” (Ahmed 2004, p.1). Showcasing the whiteness of curricula makes it visible to white people. For non-whites, the practice aims to re-classify the putatively benign or universal as biased curricula that produce both privilege and disadvantage.

At its core, a curriculum is not a reading list but an epistemological gateway into a discipline. We identify the concepts we favour and situate them in relation to others, assigning materials that verify our position. Epistemological influences are ever present. Curriculum researchers, for example, study curricula not as banks of material but as meta-cognitive processes that produce, concurrently, the canonisation and denigration of distinct forms of knowledge. Power relations feature heavily in their investigations and are relevant to decolonisation, exposing the challenges of curricular reform when tied to histories of oppression and epistemic erasure (Moreno 2007, p. 195).

As per Ngugi, for a decolonised approach to succeed, it must rehabilitate perceptions of the local. 'At each stage of experimentation and development the return 
to the local should inspire the means for encouraging an openness toward the past colonial experience and an openness toward a future that does not preclude new ways of thinking and doing' (Peters 2019, p. 147). Achieving a decolonised curriculum involves diversifying readings, to be sure, but more important is divesting curricula of the colonial traumas that often undergird them. Quoting Aimé Césaire, Heleta argues that 'decolonisation is about the consciousness and rejection of values, norms, customs and worldviews imposed by the [former] colonisers' (Heleta 2016, p. 5). We achieve this by cultivating students' awareness of local histories and knowledge systems (Waghid 2016, p. 204-205). Returning to decolonial scholars like Mignolo, we subvert epistemic erasure by rehabilitating regional epistemologies or, as they assert, by embracing the pluriverse.

From history to economics, anthropology to business studies, many academic disciplines are guilty of mainstreaming Western scholars and the Western canon at the expense of other epistemologies. They also whitewash colonialism from their fields of study, often dismissing it altogether. They even treat the legacies that reverberate across facets of human existence as ahistorical. International law is egregious in this regard. A glance at the main textbooks reveals the hegemony of Eurocentrism and of whiteness.

'Today, like yesterday, legal education persists in centring the European white male, an overrepresentation that translates into a suffocating outlook. Mainstream international legal history, as we portray it, furnishes a glowing example: Francisco de Vitoria was a Spanish-Catholic theologian in the court of Ferdinand and Isabella; Hugo Grotius was in-house counsel for the Dutch-East India Company; Emer de Vattel, the son of a Swiss-Protestant clergyman, read Christian theology and metaphysics; John Westlake of Cornwall lectured at Cambridge and was the British delegate at the International Court of Arbitration; Lassa Oppenheim studied law in Germany before emigrating to England to take up appointments at the LSE and Cambridge; and Hersch Lauterpacht was Polish and also served at the same institutions. All were European, white, male, and paramount in developing Eurocentric international law (al Attar 2021, p. 184).

As interlocutors for a universal legal regime, these scholars are taught in law schools everywhere, ensuring that Eurocentrism circulates at both aetiological and epistemological levels. This is unsurprising since the authors of the most popular textbooks on international law include Malcolm Shaw, Ian Brownlie, Malcolm Evans, James Crawford, and Jan Klabbers. Even across the Third World, we are more likely to encounter these same texts or translations thereof. International law lecturers are trapped in a publishing wasteland as white male authors exert a lock over introductory texts, undermining the diversity of perspectives needed to legitimise and to advance the regime.

As per the textbooks on international law, Europe's behaviour and organisational preferences are represented as universal. Europe arrogated to itself rationality, objectivity, and science. What is left for non-Europeans but irrationality, subjectivity, and mysticism? Peters voices this critique, situating it within the parochialism 
of academic thinking. Implicitly drawing on political philosopher Nancy Fraser, he bemoans the 'lack of recognition of cultural context... [that results in] no historical understanding of evolving forms of knowledge let alone their cultural variation' (Peters 2015, p. 644). Legal academics teach students that European doctrines and ways of knowing possess objective value. Ways of knowing from other regions are equally edifying so long as they cohere with the master form.

There are a few approaches to addressing what is now recognised as the inescapable issue of Eurocentrism. One consists of what might be termed "ornamentalism", the inclusion in a textbook-and this is becoming something of a trend-of a passage or two on other traditions of international law, a nod to the rich heritage and history of India and China for instance. This approach acknowledges other civilisations without asking hard questions about the relationship between them and European international law, or disturbing in any respect the traditional narrative (Anghie 2020).

For a mix of reasons, authors of international law textbooks are committed to denying the constitutive character of Europe's predatory practices. Despite their contribution to the foundations of international law, European genocides across the Americas and beyond and even the transatlantic slave trade are omitted wholesale. The omission is made all the more glaring by the plethora of works emerging from TWAIL scholars that evidence the many ways imperialism, colonialism, and the slave trade shaped international law's trajectory. Yet, authors of the major textbooks on international law continue to silence this strand of scholarship.

Other themes and epistemologies are also excluded. '[C]onsider the following omissions and their ramifications for law students in the Third World' argues al Attar (2021, p. 186). 'Absent [from the core textbooks] is substantive reflection on R.P. Anand, the Arawak, Bandung, Mohammed Bedjaoui, Carlos Calvo, Confucian philosophy, the German genocide of the Herero and Nama, Taslim Olawale Elias, and Christopher Weeramantry' To the extent that the authors practise Anghie's ornamentalism, other traditions are presented in reductive terms. In Klabbers' text, 'Islamic states and Islamic Law enjoy cameos [but only] to further the canard about intrinsic gender bias' (al Attar 2021, p. 186). While Shaw invokes equivalence between the European worldview and the civilisational traditions of others-notably China and Islam-he fails to engage with them to any degree of rigour. For example, he mentions Islam's relationship to international law, once, referencing a nonexpert: 'Even when reporting on Islamic international law, Shaw prefers a foreign neophyte to a native expert of the Siyar' (al Attar 2021, p. 186). He is equally dismissive of Chinese epistemology and influence, proclaiming that 'law never attained the important place...that it did in European civilisation' a claim that would perplex legal scholars from the region (Shaw 2017, p. 27).

If scholars in other regions of the world authored textbooks, would scholarly representations of international law achieve greater inclusivity? We return to the cogent observation of the student collective: the white curriculum need not only include white people. Censorship notwithstanding, when applying the nuance prescribed by Ahmed, we recognise that racial inclusion is insufficient to disrupt Eurocentrism in international law. Rather, it racialises non-white agencies while naturalising racial 
identification. Recall Afsah's quip about the non-contingency of international law (Anghie and Real 2020). He is not the only one who holds this view. For example, the Teaching and Researching International Law in Asia report validates the penetration of Eurocentrism across the Asian continent. Participants favour doctrinal expositions of the subject, guided by European texts. African and South American scholars verify the same in their law schools as well.

Rigour in decolonising the curriculum demands something more: '[the] change at universities must entail "decolonising, deracialising, demasculanising and degendering" the institutions as well as "engaging with ontological and epistemological issues in all their complexity, including their implications for research, methodology, scholarship, learning and teaching, curriculum and pedagogy' (Heleta 2016, p. 5). To think of the curriculum is to think of the way we conceptualise the nature of the discipline and the associated pedagogy. Many scholars believe that '[c]urriculum might at first glance appear to be about the economics and pragmatics of teaching, about arranging content and assignments, apportioning time on timetables, and allocating resources,' Stephen Petrina observes (2004, p. 83). Yet, most scholars recognise that 'mundane and profound judgements are made when we plan, shape and judge human experience' as we do when deciding what to teach (Petrina 2004, p. 83). It is a 'moral and political endeavour' of the highest order (Petrina 2004, p. 83).

In this regard, to think of law is also to think about human experience, and the texts we select convey an interpretation of that experience and the underlying epistemology. To illustrate, law informs our understanding of equality. In doing so, it also defines race, gender, and class just as it does for racism, sexism, and classism. Law also affects how each of these categories interacts with notions of (juridical) justice, including economic distribution, political representation, and cultural recognition. The choices academics make about reading lists inform how students come to understand and naturalise these categories and the moral validity of the legal interventions. Just as the ethnic and gender diversity of the scholars is essential, perhaps more important than this are the perspectives they proffer, hence the purchase of thinking about pedagogy through the lens of epistemology or, to make the point evident, epistemologies. As Petrina proclaims, asking 'what should be learned is another way of asking what knowledge is of most worth' (Petrina 2004, p. 84). The split is epistemological but also political and personal.

In this way, the contemporary decolonising the curriculum movement appears nebulous: decolonisation is whatever its practitioners wish it to be. The freedom may be deliberate, but this amounts to abandoning both strategy and outcome to the predilections of the individual. If academia's colonial character is systemic in much the same way that colonisation was, then a free-for-all strategy is more symbolic than substantive. Heleta argues that the purpose of decolonisation is to free education from "Western epistemological domination, Eurocentrism, epistemic violence and world views that were designed to degrade, exploit and subjugate people" (2016, p. 5). Yet, just as decolonisation accepted the nation-state framework, so too does a decolonised international legal pedagogy begin with a commitment to the validity of European international law. Historically an accoutrement to power, international law legitimised colonialism, slavery, and genocide at various stages of its development. It continues to legitimise the legacies that result from the period of European 
imperialism and colonialism. For legal scholars sympathetic to decolonisation, it is the law itself that poses the greatest obstacle to a decolonisation agenda and we are doubtful whether this can ever be decolonised.

In our next section, we discuss the epistemological entrapments that pervade the decolonising the curriculum movement.

\section{Epistemological Entrapments in Decolonising the Curriculum Practices}

As inferred across our analysis, we are weary of the reformist rhetoric of the decolonising the curriculum movement. Our reservations rest with the ubiquity of epistemological entrapments that manifest in three ways: first, the meaning and aim of decolonisation is contentious even among anti-colonialists; second, the practice is sufficiently malleable to accommodate all perspectives including those who confine decolonisation to managerial forms of inclusivity; and third, the movement mischaracterises epistemological struggle as behavioural reform. We take each in turn.

First, during the decolonisation era, the heterogeneity of post-independence ambition was subsumed into pleas of sovereign recognition as nation-states. Awareness of that absorption is effaced in the institutionalisation of the call to decolonise the curriculum. Ignoring the range of political aspirations of the postcolonial period reflects a tendency to classify radical moments within a teleological ordering of history. Decolonisation becomes an event-a successful one-that ended with the attainment of political independence. What is more, the movement endorses decolonisation as a symbol of emancipation despite its contentious political context and controversial history. In the end, decolonisation practices and tensions of the earlier period are jettisoned in favour of a symbolic decolonisation, its progressive credentials presumed rather than problematised. Decolonisation arises as a signifier of recognition, reinventing a complex process and struggle as a presumptively emancipatory praxis.

Next, decolonising the curriculum appears to echo Mignolo's epistemic disobedience. It aims to delink the intellectual from a certain episteme within disciplinary boundaries, but it does not dismantle existing knowledge systems (Mignolo 2015). For Mignolo, decolonisation reworks dominant pedagogical modalities, critiquing the intellectual's positionality in the flow of knowledge and presuming that this action will precipitate critical awareness among students. However, calls to decolonise do not extend the agency of students beyond the classroom. Unlike actual decolonisation, a curricular movement fails to induce social mobilisation beyond the academe, leaving it vulnerable to idiosyncrasies and perversions of the modern university. For example, consider the following communication from the administration at a Russell Group University regarding their efforts at pedagogical reform. The message was sent to academic staff: 'As part of Faculty X's decolonising the curriculum effort, we're planning to publicise information on our website about which modules have been decolonised so far. I'd be grateful if colleagues who have decolonised their curricula would let us know which modules have been completed.' Having entered the managerial lexicon, the university reduces decolonisation to a 
tick box and promotional campaign, with possible implications for career progression. Such co-option is inevitable when symbolism supplants systemic renewal. The decolonising the curriculum movement does not operate beyond the university. Rather, it is an intellectual attempt to distance oneself from persisting colonial practices exhibited within academia.

In The Undercommons, Stefano Harney and Fred Moten, (2013) problematise the effects of professionalisation on the ordering of knowledge systems within universities. Professionalisation happens through the reproduction of authoritative disciplinary boundaries and the surveillance of intellectual agencies. Regulative mechanisms define the impact and value of those agencies. Such value does not escape racist and classist stratification that reproduce exclusions of those who are most vulnerable to and burdened by, the demands of the academic institution. Decolonisation of the curriculum becomes a subset of exclusions as an institutional demand that sustains the university's central role in knowledge production. The pedagogical aims of decolonising the curriculum movement produce a conviction that the movement is not isomorphic with the exclusionary role of the university.

More problematic for the decolonisation movement is not the hegemony of the epistemology alone, but the active rejection of traditions that fall outside of the interpretive frames. As Sylvia Wynter contends, discourse entrapments reinforce hierarchies in the ordering of knowledge, while subjugating alternative orders under a homogenised episteme (1987). But without introducing alternative traditions on societal relations into the conversation, we fail to counter the foundation of the colonial campaign: '[this] hegemonic tradition also actively represses anything that actually is articulated, thought and envisioned from outside of [its] frames' (Mbembe 2016 , p. 33). Here what to learn is substituted with what to think or, more accurately, from within which tradition should we think?

This problem is especially pervasive in relation to international law where, as we have argued, the contours are colonial in character and function. Even (critical) international legal scholars deploy critique within disciplinary boundaries to reenchant international law through a critical wariness of its origins and the epistemologies that reproduce Eurocentrism, yet that always ends in its embrace. ${ }^{3}$ Developing a decolonising agency thus attends to the demands of the status quo. Within the academe, scholars are conditioned in their pedagogy to the epistemes that are acceptable within the existing horizon of knowledge (Harney and Moten 2013, p. 34). Critical scholarship reflects the 'professional course of action' in the face of the failures of the academic institutions to be more hospitable to excluded sources of knowledge (Harney and Moten 2013, p. 112). In the context of international law, scholars and students alike are limited in their critical awareness to the boundaries established by Eurocentrism. Even a decolonised international legal curriculum demands supersession rather than the abolition of the categories that sustain a European episteme.

\footnotetext{
${ }^{3}$ On discussion on paradoxes within the aims of critical international legal scholars, see al Attar (2020, p. 195).
} 
We conclude this section with our third concern where decolonisation as a symbol interlopes as a behaviour or a protective act against institutional marginalisation. What decolonisation offers is a momentary relief-in the form of recognition-against exclusion for scholars who occupy liminal spaces within academic institutions. But such relief operates through a neurotic belief that declares critical agency as a privilege, while exhibiting deep dissatisfactions with international law as a discipline. A neurotic agent is incapable of expressing their frustrations with current repressions; they resort to sustaining power relations that reproduce their dissatisfactions by claiming the grandeur of a decolonised curriculum. In the postcolonial context, Fanon reminds us that such neurosis leaves the excluded subjects incapable of expressing their frustrations against the promises of assimilation to modernity (Fanon 2008, p. 43). Minor improvements within the 'inclusivity' of the curriculum are not counter-hegemonic or even decolonising: they feed and reproduce neurosis while pacifying the potential for social change. As a neurotic behaviour, decolonising the curriculum consumes the space for critical conversations. Exposing the epistemic entrapment of international legal reproduction becomes an aim in itself that can be remedied through an acknowledgement of Eurocentricity, while we remain deeply dissatisfied with international legal praxis. How else could we accept the emancipatory potential of international law through decolonisation while its imperialist practices and outcomes persist?

Engaging with Fanon's diagnosis of the postcolonial condition, Wynter clarifies that such neurotic practices require a disenchantment with the order of knowledge itself. To disenchant discourse is to explore different 'objects of knowledge' (Wynter 1987, p. 207). Unlike decolonisation, disenchantment opens up a speculative space to those objects that do not fit within the dominant epistemology. Disenchantment forces us to be attentive to the complexities in decolonisation (like decoloniality) that are not merely pedagogical questions as the decolonising the curriculum movement frames them. Rather, the complexities of decolonisation concern the implications of assuming a decolonised consciousness, while a purification from the violence of colonialism is impossible.

The multiple and repressive origins of international law, which we identified earlier, communicate to us that an epistemological shift on how we produce knowledge in the international space will not start with decolonisation but with the abolition of the afterlives of slavery that continue to condition the agencies of Third World societies in international legal praxis. Rather than assimilating an ahistorical diversification of the international legal curriculum, we might attend to the reasons international law continues to reproduce the ills upon which it was fashioned. A decolonised agency is incapable of such attentive work. Instead, it regulates the repressive origins of international law so that we remain enchanted with international law, leading us to conclude that, in the context of international legal pedagogy, decolonisation is detached from its radical potential. In our final section, we engage with how to return to and fixate on this potential. 


\section{Disenchantment Contra Redemptive Pedagogy}

Disenchantment initiates with a belief that we have not surpassed colonial relations and that societal agencies are conditioned in a stratifying and racialising international legal order. TWAIL scholars have engaged with alternative ways to teach and engage with international law to move beyond the persistent colonial relationalities that are produced and eased through the international legal order (Achiume and Carbado 2021; Bhatia 2018; Fagbayibo 2019) These voices have been attentive to the epistemological limitations in instrumentalising international law for emancipatory rhetorics and that we have argued are unresolvable with decolonising the curriculum. For example, the recent merging of critical race studies and TWAIL is building momentum toward explaining the inseparable link between racism in America and persisting colonial relations that shape the agencies of formerly colonised societies. (Achiume and Carbado 2021) Achiume and Carbado treat the intersection between critical race studies and TWAIL as thematic transpositions (2021, p. 1464) Another example of a common thread between TWAIL and critical race studies is the stratifying inclusivity that the doctrine of recognition evokes in the context of gaining sovereign independence and in relation to granting African Americans the right to vote. The problem of sovereign recognition in TWAIL is limited to understanding the afterlives of colonial governance in the criteria of statehood and dismisses the naturality of racial identification in the international realm (Achiume and Carbado 2021). In critical race theory, the limitations of acquiring legal rights are traced to persisting racial relations that limit the exercise of those rights, while downplaying the role of colonial relations in determining who qualifies as a rights-bearing individual. (Achiume and Carbado 2021) Identifying thematic transpositions between both critical movements can be utilised in teaching international law to first, understand the function of international law in naturalising race as a category of identification. Second, the practice can expand the boundaries of both intellectual movements (critical race studies and TWAIL) in relation to how the epistemological problem is shaped in teaching international legal praxis.

Through disenchantment (as in rejecting the international legal order as a totalising knowledge regime), thematic transpositions between both critical movements signpost to us that the problem is not how we teach international law but that the epistemological parallels in both movements are essentially racialising. For example, both TWAIL-ers and critical race theorists have argued that inclusivity-in terms of sovereign recognition in TWAIL or acquiring citizenship rights in critical race theory-can also be a source of subordination (Achiume and Carbado 2021, p. 1471; Coulthard 2014; Hartman 1997). Essential to this argument is that we cannot escape what Hartman refers to as "the entitlements of whiteness" that propagates the idea of "formal equality" while such equality happens in an abstracted manner; it is the same sense of equality that was one of the pillars of colonial empires that saw black people as property (Hartman 1997, p. 116). Similarly, Coulthard's thesis demonstrates the subsumption of indigenous land claims and indigenous sovereign recognition in neo-colonial relations in 
Canada and traces it to the processual primitive accumulation in colonial empires (Coulthard 2014, p. 53). Hartman's and Coulthard's theses suggest that recognition restrains actual freedom and highlights the intentionality of the sustenance of imperial and racialising relations.

What we learn from the synergies (and limitations) of both critical race theory and TWAIL is that the main intellectual and pedagogical dilemma is not that we cannot rehabilitate international legal education through decolonising the curriculum (al Attar 2014). It is that such rehabilitation often happens through teaching it as a critique of eurocentricity (al Attar 2021). One way of remedying that is to contextualise and acknowledge different social realities that affect how students come to relate to international law. Treating TWAIL as a pedagogy fosters a relationality that surpasses the assumption that teaching critical international law is making sense of and moving beyond a colonial past (al Attar 2021, p. 190). Rather, TWAIL pedagogy situates the aspirational ideals of international law in its colonial function and, as such, the role of decolonising the curriculum is to expose the preservation of colonial relations in the present and futures of international law. Here, decolonising the curriculum appears as a 'revision' of textbooks and scholarly interventions (al Attar 2021, p. 190). With such alterations to international legal curriculums, the very possibility of decolonising international law is to make it relevant to our social realities. In doing so, it sustains racial relations as the only modality of understanding and making sense of those realities and it ultimately inhibits students from coming to a (legal) consciousness that rejects colonial hereditarianism.

For us, the question is not on how to teach international law differently. It was never our intention to offer a different way of decolonising international legal curricula. Instead, we have engaged with the expectations of the pedagogical turn to decolonisation absent the context of its colonial realities. Alternatively, we ask, with the persistence of colonial relations in the international order, as many TWAIL-ers have argued, can decolonising the international legal curriculum envision the conditions of (actualised) postcoloniality? In answering this question, we reject the utility of international law in offering a different reality that actualises postcolonial conditions through decolonising the curriculum.

Our framing of the problem illustrates the epistemological entrapments in decolonising international legal curriculum movement and its failures to answer to the continuous colonial and racialising relations. Coming to a decolonial consciousness through international legal education becomes the very source of dissatisfaction, as students achieve critical agencies without alternatives to racialising relations. We have suggested that this form of consciousness is neurotic in nature and incapable of envisioning global relations beyond a stratifying international legal order. For that, the article calls for seeing the problem differently by unbinding the praxis of decolonising the curriculum as an institutional movement. In necessitating decolonial praxis, decolonising the curriculum reduces decolonisation to an institutional demand. We become aware of the performative aspect of the exercise, which on the one hand, offers diverse voices (that does not necessarily mean different narratives) and, on the other, instrumentalises the potentiality in struggles of decolonisation to reinvigorate the function and utility of international law in our contemporary relations. 
Our critique is not only directed at decolonising the curriculum as an institutional movement. It also extends to the practice of decolonisation and, specifically, the critical consciousness that it nurtures. In relation to that consciousness, we have signposted a distinction between the demand for sovereign emancipation that traversed decolonial praxis in formerly colonised societies in earlier sections and the obstruction of postcolonial relations through the sustenance of racial governance in international law. This distinction leads us to think that to understand what it takes to envision a postcolonial reality, teaching international law might mean going beyond international legal relations in alternative praxis and views on an international order. Those alternatives exist, as we suggested when dealing with struggles for decolonisation in earlier sections. But they exist, perhaps, shadowed by the grandeur of international legal expertise that consumes their potential when reaffirmed through the decolonising the curriculum movement.

\section{Conclusion}

Etymologically, enchantment represents a continuous song, one that changes its sound from time to time to immortalise its spell. Despite its violent origins, there are plenty of enchantments with international law as an order of fundamental knowledge. Likewise, the enchantment of decolonisation is spreading and has acquired resonance within academic institutions. The decolonising the curriculum movement has built its legitimacy on a symbolism that obviates the persistence of Eurocentrism. This is especially acute within international law where the movement fosters the critical agencies of scholars and students while blinding them to international law's reactionary character and its parochial epistemology.

Our critique navigates the practical effects of decolonisation-as diversification praxis-and its inherent entrapments: decolonisation fails to highlight the epistemological closures within the international legal order. We suggest the process of diversifying international legal curriculum becomes a neurotic behaviour that reinvigorates international law while reiterating its Eurocentricity as the foundation of international legal praxis, knowledge, and pedagogy. In the process, the critical international legal scholar exhibits a form of agency that is incapable of capturing the persistent failures of international law. After all, to enchant is to ease the burden on oneself.

Acknowledgements We thank the anonymous reviewers and editors of Law \& Critique for their feedback. We're also grateful to a long line of critical scholars who have enriched our thinking about both decolonisation and emancipation, symbiotic concepts and praxes.

Open Access This article is licensed under a Creative Commons Attribution 4.0 International License, which permits use, sharing, adaptation, distribution and reproduction in any medium or format, as long as you give appropriate credit to the original author(s) and the source, provide a link to the Creative Commons licence, and indicate if changes were made. The images or other third party material in this article are included in the article's Creative Commons licence, unless indicated otherwise in a credit line to the material. If material is not included in the article's Creative Commons licence and your intended use is not permitted by statutory regulation or exceeds the permitted use, you will need to obtain permission 
directly from the copyright holder. To view a copy of this licence, visit http://creativecommons.org/licen ses/by/4.0/.

\section{References}

Achiume, Tendayi. 2019. Migration as ecolonization. Stanford Law Review 71 (6): 1509-1574.

Achiume, Tendayi, Devon W. Carbado. 2021. Critical Race Theory Meets Third World Approaches to International Law. U.C.L.A Law Review 67: 1462-1502.

Ahmed, Sara. 2004. Declarations of whiteness: the non-performativity of anti-racism. Borderlands e-Journal 3 (2): 1-12. https://doi.org/10.1177/1464700107078139.

Ahmed, Wahida, Hezhan Kader, Abdul Khan, Ahmed Memon, Joy Olugboyega, Anthony Otobo Martins, Mekke Orie, Jasmyn Sargeant and Lisa Shoko with Suhraiya Jivraj and in collaboration with Dave Thomas and Sheree Palmer. 2019. Decolonising the Curriculum Project: Through the Kaleidoscope. https://decoloniseukc.files.wordpress.com/2019/03/decolonising-the-curriculum-manifesto.pdf. Accessed 6 March 2021.

al Attar, Mohsen. 2014. Reframing the "universality" of international law in a globalizing world. McGill Law Journal 59 (1): 95-139.

al Attar, Mohsen. 2020. TWAIL: a paradox within a paradox. International Community Law Review 22 (2): 163-196.

al Attar, Mohsen. 2021. Must international legal pedagogy remain eurocentric? Asian Journal of International Law 11 (1): 176-206.

Anghie, Antony. 1996. Francisco de vitoria and the colonial origins of international law. Social \& Legal Studies 5 (3): 321-336. https://doi.org/10.1177/096466399600500303.

Anghie, Antony. 1999. Finding the peripheries: sovereignty and colonialism in nineteenth-century international law. Harvard International Law Journal 40 (1): 1-80.

Anghie, Antony and Robert G. Real. 2020. Teaching and Researching International Law in Asia (TRILA) Project Report. NUS Centre for International Law.

Anghie, Antony. 2020. Critical Pedagogy Symposium: Critical thinking and Teaching as Common Sense-Random Reflections. Opinio Juris. http://opiniojuris.org/2020/08/31/critical-pedagogysymposium-critical-thinking-and-teaching-as-common-sense-random-reflections/ Accessed 6 March 2021.

Barreto, José-Manuel. 2018. Decolonial thinking and the quest for decolonising human rights. Asian Journal of Social Science 46 (4-5): 484-502.

Bhatia, Amar. 2018. Re-Peopling in a Settler-Colonial Context: The Intersection of Indigenous Laws of Adoption with Canadian Immigration Law. AlterNative: An International Journal of Indigenous Peoples 14 (4): 343-353.

Bird, Schucan K., and Lesley Pitman. 2020. How diverse is your reading list? exploring issues of representation and decolonisation in the UK. Higher Education 79: 903-920.

Coulthard, Glen Sean. 2014. Red skin, white masks: rejecting the colonial politics of recognition. Minneapolis, Minnesota: University of Minnesota Press.

Douzinas, Costas. 2003. Humanity, military humanism and the new moral order. Economy and Society 32 (2): 159-183.

Dussel, Enrique. 2013. Las Casas, Vitoria and Suarez, 1514-1617. trans. by James Terry. In Human Rights From a Third World Perspective: Critique, History and International Law, eds. José-Manuel Barreto. 173-205. Cambridge Scholars Publishing.

Fagbayibo, Babatunde. 2019. Some thoughts on centring pan-African epistemic in the teaching of public international law in African universities. International Community Law Review 21 (2): 170-189.

Fanon, Frantz. 2008. Black Skin, White Masks. London: Pluto Press.

Gouduka, I.N. 1996. Challenges to traditionally white universities: affirming diversity in the curriculum. South African Journal of Higher Education 10 (1): 27-34.

Grear, Anna. 2012. "Framing the project" of International Human Rights Law: Reflections of the Dysfunctional 'Family' of the Universal Declaration. In The Cambridge companion of human rights law, eds. Conor Greaty and Costas Douzinas. 17-35. Cambridge University Press.

Harney, Stefano and Fred Moten. 2013. The Undercommons: Fugitive Planning and Black Study. Minor Compositions. 
Hartman, Saidya. 1997. Scenes of subjection: terror, slavery, and self-making in nineteenth century America. Oxford: Oxford University Press.

Heleta, Savo. 2016. Decolonisation of Higher Education: Dismantling Epistemic Violence and Eurocentrism in South Africa. Transformation in Higher Education 1 (1).

Klabbers, Jan. 2020. International Law. Cambridge University Press.

Lugones, Maria. 2010. Toward a decolonial feminism. Hypatia 25 (4): 742-759.

Mamdani, Mahmood. 2016. Between the public intellectual and the scholar: decolonisation and some post-independence initiatives in African higher education. Inter-Asia Cultural Studies 17 (1): 68-83.

Mbembe, Joseph A. 2016. Decolonising the university: new directions. Arts and Humanities in Higher Education 15 (1): 29-45.

Mignolo, Walter, and Arturo Escobar, eds. 2010. Globalisation and the Decolonial Option. London: Routledge.

Mignolo, Walter D. 2015. Sylvia Wynter: What Does It Mean to Be Human? In Sylvia Wynter: On Being Human as Praxis, ed. Kathrine McKittrick, 106-123. Durham, North Carolina: Duke University Press.

Mignolo, Walter, and Catherine E. Walsh. 2018. On Decoloniality: Concepts, analytics, praxis. Durham, North Carolina: Duke University Press.

Mohanty, Chandra Talpade. 2003. Feminism without borders: decolonising theory, practicing solidarity. Durham, North Carolina: Duke University Press.

Moreno, Juan Manuel. 2007. The Dynamics of Curriculum Design and Development: Scenarios for Curriculum Evolution. In, School Knowledge in Comparative and Historical Perspective, eds. Benavot Aaron and Cecilia Braslavsky. Springer, Dordrecht.

Natarajan, Usha, John Reynolds, Amar Bhatia, and Sujith Xavier. 2016. Introduction: TWAIL: on praxis and the intellectual. Third World Quarterly 37 (11): 1946-1956.

Nesiah, Vasuki. 2018. Decolonial CIL: TWAIL, feminism and an insurgent jurisprudence. AJIL Unbound 112: 313-318.

Ngugi wa Thiong'o. 1986. Decolonising the mind: the politics of language in African literature. London: James Currey.

Ngugi wa Thiong'o. Mar Apr 1985 The Language of African Literature The New Left Review 1150109 127

Pahuja, Sundhya. 2011. Decolonising international law: development, economic growth and the politics of universality. Cambridge: Cambridge University Press.

Peters, Michael A. 2015. Why is my curriculum white? Educational Philosophy and Theory 47 (7): 641-646.

Peters, Michael A. 2019. Manifesto for the postcolonial university. Educational Philosophy and Theory 51 (2): 142-148.

Quijano, Anibal. 2000. Coloniality of power and eurocentrism in Latin America. International Sociology 15 (2): 215-232.

Said, Edward. 1978. Orientalism. London: Routledge.

Shaw, Malcolm. 2017. International law (8th ed.) Cambridge: Cambridge University. Press.

Spivak, Gayarti Chakravorty. 1988. Can the Subaltern Speak? In. Marxism and the Interpretation of Culture, ed. Nelson, Cary and Lawrence Grossberg . 271-313. Macmillan Education: Basingstoke.

Stephen, Petrina. 2004. The politics of curriculum and instructional design/theory/form: critical problems, projects, units, and modules. Interchange 35: 81-126.

Waghid, Yusef. 2017. Does a white curriculum matter? Educational Philosophy and Theory 49 (3): 203-206.

Wynter, Sylvia. 1987. On disenchanting discourse: "minority" literary criticism and beyond. Cultural Critique 7: 207-244.

Publisher's Note Springer Nature remains neutral with regard to jurisdictional claims in published maps and institutional affiliations. 